\title{
The Double Nature of DNA: Reevaluating the Common Heritage Idea
}

\author{
MATTHIEU QUELOZ \\ Philosophy, University of Zurich
}

Eversing three decades of patenting policy, the U.S. Supreme Court unanimously
ruled on June 13, 2013, that naturally occurring DNA was not patent eligible. Before this decision, over twenty per cent of human genes were subject to patents-a fact which had widely gone unnoticed until the American Civil Liberties Union (ACLU) and the Public Patent Foundation (PPF) filed a lawsuit in the Federal District Court in May 2009. They sued not only the U.S. Patent and Trademark Office (USPTO), but also the biotech company Myriad Genetics, whose patents on genes associated with hereditary breast and ovarian cancer, $B R C A 1$ and $B R C A 2$, were among the few to be enforced. This trial generated a heated public debate over the patentability of human genes. It emerged from this debate that people's intuitions about human genes conflict with the practice of patenting them. Gene patents were viewed as a threat to the progress of science, the accessibility of health care, our ownership of our own bodies, and human dignity itself. But one conception in particular came to dominate the legal and political debate: the view that the human genome forms part of the common beritage of mankind. ${ }^{1}$ Many divergent intuitions are rallied under this heading, but this common heritage idea (CHI) has become the master argument in attempts to give voice to the sentiment which James Watson, co-discoverer of DNA, expressed in one of 49 amicus curiae briefs: "Life's instructions ought not be controlled by legal monopolies created at the whim of Congress or the courts."2

\footnotetext{
B. M. Knoppers writes: "At the international level, there is increasing recognition and confirmation that ... the human genome is the common heritage of humanity" (Bartha Maria Knoppers, "Biobanking: International Norms," The Journal of Law, Medicine ES Ethics 33.1 (2005), 7-14 at p. 11). Also, both the Human Genome Organization and the UNESCO's Universal Declaration on the Human Genome and Human Rights designate the human genome as a part of the "common heritage of mankind." See The Human Genome Organization, "Statement on the Principled Conduct of Genetics Research," Eubios Journal of Asian and International Bioetbics 6.3 (1996); Noelle Lenoir, "Universal Declaration on the Human Genome and Human Rights: The First Legal and Ethical Framework at the Global Level," Columbia Human Rights Law Review 30 (1999).

2 James Watson, "Brief amicus curiae of United States in support of neither party," Association for Molecular Pathology v. Myriad Genetics 569 U.S. 12-398 (2013).
} 
Yet in this same brief, Watson went on to draw attention to the fact that DNA possesses a peculiar double nature. It is, he says, only the

... myopic viewpoint [which] thinks of a human gene as merely another chemical compound, composed of various bases and sugars. But history and science teach us otherwise. A human gene, which is a product of nature, is useful because it conveys vital information. ${ }^{3}$

This passage brings out that DNA is both an analog chemical compound and a carrier of digitally encoded information. Moreover, it highlights that while it is under the first aspect that DNA is a product of nature, which is a criterion for exclusion from patentability, it is under a different aspect, namely as a carrier of information, that it is "useful" - which is a criterion for patentability. The tension between these countervailing descriptions raises the question whether, by distinguishing rigorously between these two aspects, the perceived conflict between the patent system and some of our intuitions about the genome can be dissolved. After a brief sketch of the patent regime's main objectives and their implementation and application to biotechnology, this paper explores the lines of reasoning that lead to the CHI. It aims to (i) reevaluate those lines of reasoning in the light of DNA's double nature, (ii) articulate and motivate what emerges as the most viable version of the $\mathrm{CHI}$, and (iii) assess the extent to which this version conflicts with current patenting practices.

The conclusion put forward in this paper is that in the light of DNA's double nature, the human genome is best thought of as a repository of information: a record of biological history and a source of future innovation that is best compared to the cultural and natural heritage. And while distinguishing the physical from the informational aspect of DNA goes some way towards dissolving the perceived conflict with patenting practices, it also brings out a sense in which the Supreme Court's ruling exploits precisely this double nature to pay but lip service to Watson's injunction to release "Life's instructions."

On the side of the patent system, its perceived conflict with people's intuitions about the human genome might derive either from its core objectives, from those objectives' implementation in the current patent regime, or from the application of patent law to a particular field or case. We can identify what are uncontroversially core objectives of the patent system by taking as our guide the World Trade Organization's legally binding Agreement on Trade-Related Aspects of Intellectual Property Rights (TRIPS), to which the United States have subscribed along with 157 other WTO members. In this agreement's formulation, the patent system's objectives are to

\footnotetext{
3 Ibid., emphasis mine.
} 
... contribute to the promotion of technological innovation and to the transfer and dissemination of technology, to the mutual advantage of producers and users of technological knowledge and in a manner conducive to social and economic welfare, and to a balance of rights and obligations. ${ }^{4}$

In the U.S., these objectives are implemented by giving inventors the possibility of applying for a patent on inventions which are demonstrably novel, non-obvious and useful. ${ }^{5}$ The legal title of a patent bestows the right (for twenty years) to prevent others from making, using, selling, offering for sale, or importing an invention without the inventor's consent. In return, the applicant must disclose all relevant information on the invention in the patent application. Patents are thus a trade-off between the protection and the disclosure of information: they incentivise discovery, investment and commercialisation by making it potentially lucrative to invest in the development of new products or processes, but they constitute an important source of technical information for the competition.

It is with the coming to maturity of biochemistry in the 1970s that patent law began to be applied to genetic material. While laws of nature, natural phenomena and naturally occurring species are excluded from patentability, the USPTO began issuing patents on DNA, a full legal justification for which was advanced only in the "Utility Examination Guidelines" of 2001. ${ }^{6}$ According to these guidelines, DNA within bodies is not patenteligible, but two other forms of genetic material are:

(1) isolated genomic DNA (gDNA): DNA fragments of various sizes that have been removed from the surrounding genome; and

(2) complementary DNA (cDNA): DNA that has been synthesised from a DNA-derived messenger RNA (mRNA) template for protein-synthesis.

The patentability of these two forms of DNA was justified primarily by two long-standing judicial doctrines. The first goes back to the dicta (assertions by judges that are neither essential to decisions nor legally binding but potentially influential) of Judge Learned Hand in Parke-Davis v. H. K. Mulford, a 1911 case which concerned a patent on adrenalin that had been produced in concentrated form. Hand declared that adrenalin, having been extracted,

\footnotetext{
4 World Trade Organization, "TRIPS: Agreement on Trade-Related Aspects of Intellectual Property Rights, Apr. 15, 1994, Marrakesh Agreement Establishing the World Trade Organization, Annex 1C”, The Legal Texts: The Results of the Uruguay Round of Multilateral Trade Negotiations (Cambridge: CUP, 1999), 319-351 at Art. 7.

5 In Europe, the legal situation is more intricate: while a supranational body of "soft law" was passed with the signing of the European Patent Convention by 38 states, patents still need to be applied for individually in every state. For this reason, this paper focuses on U.S. patent law, and its wider relevance might be seen to lie in examining what the implications would be of having a U.S.-style gene patenting regime enacted worldwide.

6 US Patent and Trademark Office, "Utility Examination Guidelines”, Federal Register 66.4 (Jan. 2001), 1092-1099.
} 
purified, and thus made useful, became "a new thing commercially and therapeutically," and that this constituted a "good ground for a patent."7 The second doctrine originated with the Supreme Court's ruling in 1980 in Diamond v. Chakrabarty, a landmark case in which a genetically modified bacterium was declared patentable. The Court argued that products of nature are eligible for patents if they display "markedly different characteristics from any found in nature." ${ }^{8}$ It is this application of patent law which historically marks the explosion of gene patents.

\section{II}

Turning to the other side of the perceived conflict, people's intuitions about the human genome, their first articulation in terms of the $\mathrm{CHI}$ goes back to the opening article of the UNESCO's Universal Declaration on the Human Genome and Human Rights, which also constitutes the first global legal and ethical framework attempting to set standards for activities in this area. "The human genome," this 1997 declaration reads, "underlies the fundamental unity of all members of the human family, as well as the recognition of their inherent dignity and diversity. In a symbolic sense, it is the heritage of humanity." 10 However, this document provides little guidance on how the concept of the common heritage of mankind is to be understood. In The Concept of the Common Heritage of Mankind in International Law, Kemal Baslar locates "the only fully-fledged development of the concept" ${ }^{11}$ in the United Nations Convention on the Law of the Sea of 1982, which declared the seabed and ocean floor to be the "common heritage of mankind"12 and vested "[a]1l rights in the resources" of that area in "mankind as a whole." ${ }^{13}$ It called for all activities in the deep sea to be carried out "for the benefit of mankind as a whole . . . taking into particular consideration the interests and needs of developing States and of peoples who have not attained full independence or other self-governing status." ${ }^{14}$ Partly for historical reasons, this instantiation of the CHI was concerned with equity. ${ }^{15}$ It turned the deep

\footnotetext{
Parke-Davis E\& Co. v. H. K. Mulford Co. 189 F. 95 (S.D.N.Y. 1911).

8 Diamond v. Chakrabarty 447 U.S. 303 (1980).

9 See Noelle Lenoir, "Universal Declaration on the Human Genome and Human Rights: The First Legal and Ethical Framework at the Global Level," Columbia Human Rights Law Review 30 (1999), 537-587.

${ }^{10}$ UNESCO, "Universal Declaration on the Human Genome and Human Rights," Records of the General Conference (Paris: United Nations Educational, Scientific and Cultural Organization, 1998), 41-46 at Art. 1.

${ }^{11}$ Kemal Baslar, The Concept of the Common Heritage of Mankind in International Law (The Hague, Boston and London: Martinus Nijhoff, 1998), p. 206.

${ }^{12}$ United Nations, "Convention on the Law of the Sea," International Legal Materials, Treaties and Agreements 21 (1982), 1261-1354 at Art. 136.

${ }^{13}$ Ibid., Art. 137, $\$ 2$.

${ }^{14}$ Ibid., Art. 162, $\$ 2$.

15 The Convention on the Law of the Sea was partly a response to the concern of less-industrialised nations that power imbalances would unjustly favour resource exploitation by more-industrialised nations.
} 
sea from a res nullius, a resource or territory belonging to nobody, into a res communis, a resource or territory belonging to everybody.

Some have thought that this conception of the common heritage can and should be extended to include the human genome. Emmanuel Agius writes: "If there is an obvious component of the common heritage of mankind, indeed, more obvious than the resources of the sea-bed itself, it is the human genetic system." ${ }^{16}$ The CHI as modelled on the Convention on the Law of the Sea, which we might call the Shared Property Heritage Idea (SPHI), might be thought to inherit from its precedent a concern for equity, on the rationale that if a resource belongs to everybody, benefits derived from its exploitation should be shared equitably, even if these benefits are the fruit of only a few people's labour. Applied to the genome, the SPHI would encourage the creation of a common property interest in a resource residing in all human cells, and provide an impetus to the equitable distribution of benefits deriving from the human genome's exploitation, making it attractive to those concerned about biopiracy, i.e. the exploitative commercialisation of products based on biological resources.

Others have been more reluctant to take up the UNESCO's suggestion. David Resnik has even argued that applying the $\mathrm{CHI}$ to the genome is incoherent. ${ }^{17}$ If we take the idea seriously, Resnik maintains, we should be able to spell out exactly what falls under it. Yet in the face of genetic variations between individuals, even this first step is problematical. Indeed, the most common type of genetic variation, a difference in a single nucleotide (called a single nucleotide polymorphism, or SNP), occurs on average once in every threehundred nucleotides. With 3 billion base pairs, one would expect roughly 10 million such SNPs in any one human genome. Resnik points out that this makes it difficult to identify a single thing or set of things constituting the human genome. ${ }^{18}$ Moreover, Resnik's second argument runs, to view the human genome as part of the common heritage is to view us as its heirs. But since we share around 98.5 per cent of our genes with chimpanzees and sizeable portions of it with other species, Resnik argues that no individual or set of individuals can legitimately lay claim to that heritage without, by the same logic, conceding a similar claim to other species, a conclusion Resnik treats as a reductio. Finally, Resnik contends that the persons who bequeathed that heritage to us cannot be identified, and neither can their intention to so bequeath it be established. ${ }^{19}$ For these reasons, Resnik concludes that the $\mathrm{CHI}$ fails to be applicable to the human genome.

\footnotetext{
${ }^{16}$ Emmanuel Agius, "Germ-line Cells - Our Responsibilities for Future Generations,” Our Responsibilities Towards Future Generations, eds. S. Busuttil et al. (Valletta, Malta: Foundation for International Studies, 1990), 133-143 at p. 140.

${ }^{17}$ David Resnik, “The Human Genome: Common Resource but not Common Heritage,” Frontis 5 (2005), 197-210.

${ }^{18}$ Ibid., p. 200.

${ }^{19}$ Ibid., p. 201.
} 
Fleshing out the CHI by relating it to the Convention on the Law of the Sea and to the double nature of DNA can help us answer Resnik's criticism. His first point boils down to a recognition of the fact that "the human genome" is a statistical concept, for which no single, natural object provides a referent. In this respect, it is no different from other statistical concepts such as "the average citizen." The scientific community does justice to this fact by working continuously on the assembly of a "reference genome," a project which, since 2007, has been in the hands of the Genome Reference Consortium (GRC). ${ }^{20}$ By determining the relative frequencies of gene variants in bomo sapiens, a reference sequence consisting of the "default" variants is constructed and accompanied by the most frequent non-default variants to reflect actual genomic diversity. ${ }^{21}$ While it might well be incoherent to speak of a common property interest in "the human genome" in the sense of such an abstract reference genome, it would make sense to speak of a common property interest in the human genome understood as a collection of individual genomes: the set of all actually occurring sequence variants. To understand the expression "the human genome" in this way is not to take it figuratively or symbolically, but merely to spell out what, if anything, falls under the term if it is taken to refer to some physical entity.

Resnik's second objection starts with the observation that only around 1.5 per cent of our DNA is specific to humans, and ends with the conclusion that we cannot coherently claim the entire genome as our heritage without granting other species property rights in proportion to their share in that genome. But this argument rests on the assumption that the $\mathrm{CHI}$ involves the ascription of common property rights to a group-such as a species-on the basis of that resource's being common to all and only members of that group. Drawing out the implications of such an assumption would lead us to designate the 1.5 per cent of DNA common to all and only humans as the common heritage of humans, and the 26 per cent of DNA shared by a set of species including humans and yeast as the common heritage of that set of species. There are many reasons to doubt that this is a conclusion we would want to endorse; the essential role played by a gene's environment (which includes the other genes in the sequence it is part of) in determining a gene's eventual effects is one of them, because it makes it problematic to speak of the 1.5 per cent of genes specific to humans as being meaningfully related to humans outside the context of the other 98.5 per cent. But even supposing that only what is the prerogative of a group can form a part of that group's common heritage - the natural resources which have already been declared constitutive of that heritage would, by parity of reasoning, equally fall prey to Resnik's objection: besides the deep sea, the moon and outer space have also been associated with the $\mathrm{CHI}$, and these are no more the prerogative of the human species than is the basic genetic

\footnotetext{
${ }^{20}$ See http://www.ncbi.nlm.nih.gov/projects/genome/assembly/grc/human/.

${ }^{21}$ Editorial, “E Pluribus Unum,” Nature Methods 7.5 (2010), 331 at p. 331.
} 
organisation of life on earth. However, no such notions of exclusive commonality underlie hitherto existing applications of the CHI. If past instantiations of the concept are any guide in the matter, the $\mathrm{CHI}$ is concerned with the distribution of benefits deriving from certain natural resources among bumans. It is therefore logically independent from the degree of our genetic proximity to other creatures.

With Resnik's third objection, which consists in the claim that we can establish neither from whom we inherit the genome nor whether it was intended to be so inherited, the ahistorical, acontextual character of what is in effect a conceptual analysis of "heritage" becomes apparent. If we grant any weight to the idea that the meaning of a doctrine such as the $\mathrm{CHI}$ is determined in part by its past application, an approach that treats the concept in complete isolation from its history and merely looks at the logical structure of the constituents of its name will appear inadequate. The precedents we have so far considered leave no room for the demand that there should be an identifiable set of individuals who intentionally bequeath us a natural resource: there is no identifiable set of people who intended us to inherit the moon, or outer space, or the sea-bed. Resnik's approach of asking "Who inherits what from whom" might provide some guidance for an initial approach to the issue, but we cannot do justice to such a politically and historically charged notion as the $\mathrm{CHI}$ if we limit ourselves to a lexical understanding of the term. Resnik's third objection thus simply fails to address what is at issue here-if we take what is at issue to be the historically mediated idea of mankind's common heritage.

If, pace Resnik, we take the CHI's application to the human genome to be coherent in principle, the question becomes what it has to recommend it. One prominent line of thought is what we may call the continuity argument: the genome is the common heritage of mankind because genes secure some form of continuity from one generation to the next. Agius, for instance, thinks that "progress in the science of genetics" has "contributed to the awareness of the physical continuity of mankind throughout time," and that, as as result, we have come to recognise that the "collective human gene pool knows no national or temporal boundaries but is the biological heritage of the entire human species." 22 Eric Juengst, though himself critical of this view, locates its appeal in the idea that the germ-line-the lineage of cells that pass down genetic information to the next generation-forms a "thread that connects all of us as one family, and through which we pass on that connection to our children, as a unique and universal human legacy." ${ }^{23}$

Yet the thought that physical continuity of the germ-line should ground its description

\footnotetext{
${ }^{22}$ Emmanuel Agius, "Patenting Life: Our Responsibilities to Present and Future Generations," Germ-Line Intervention and Our Responsibilities Towards Future Generations, eds. E. Agius et al. (Dordrecht: Springer 1998), 67-84 at p. 76.

${ }^{23}$ Eric T. Juengst, "Should we Treat the Human Germ-Line as a Global Human Resource?", Germ-Line Intervention and Our Responsibilities to Future Generations, eds. E. Agius et al. (Dordrecht: Springer, 1998), 85-102 at p. 86.
} 
as the common heritage of mankind quickly runs into difficulties. Germ-line cells form a link between generations of organisms in that germ cells give rise to eggs or sperms, a subset of which then constitute the first cells of the next generation of organisms. But as soon as we ask how continuity is secured at the level of generations of cells, things get murkier. If it is physical continuity we are looking for, it would need to be preserved in individual molecules persisting through each cell division, but since we are talking about living cells undergoing metabolic processes that involve the constant building up and breaking down of cellular components, this is a hopeless prospect. Rather, any useful concept of cellular identity will have to be a functional one, and will thus involve the genetic information carried by the cell. Hence, whatever continuity obtains between each generation will be continuity of genetic information, and not of germ-line cells, which are only its physical substrate. And as Juengst points out, even this continuity of information is limited: the term "germ-line" picks out the lineage of dividing germ-cells which begins with an organism's zygote stage and ends in its gametes, but the next zygote, instead of resulting from a further division within that lineage, combines the end-products of two lineages to found a new germ-line whose genetic information differs substantially from that of its parent lineages. This is what distinguishes sexual eucaryotes from asexual organisms forming continuous lineages of mitotically dividing cells. ${ }^{24}$ The continuity argument is thus better suited to amoeba than to human beings.

In fact, it is rather lack of continuity which advocates of the CHI should be concerned with. No matter how much diachronic continuity the gene pool exhibits, we still face the problem that synchronically, it differs from the deep sea or the moon in being a fragmented and utterly discontinuous collection of resources residing in multiple cells within multiple bodies, which, moreover, is partly internal and partly external to the bodies of the property holders. This is a serious problem, because the idea that we should partake in common property rights to something that is partly in our own and partly in other people's bodies conflicts with other beliefs about autonomy and self-ownership. ${ }^{25}$ If the heated debate over gene patents has shown anything, it is that the belief that we should not own each other's bodies or their constituents is widely and strongly held. From this perspective, the CHI merely displaces the problem: it takes away the property rights of a few patentees only to grant them to humanity as a whole. Pilar Ossorio has concluded from this that the $\mathrm{CHI}$ is ill-suited to set the terms for the debate, for it will hardly be satisfactory to one who holds that nobody should own our genes to propose that everyone does.

At first sight, this might seem too swift. Talk of ownership gets its content by excluding a set of people from freely disposing over a particular object. Owners are granted rights

\footnotetext{
${ }^{24}$ Ibid., p. 88.

${ }^{25}$ See Pilar N. Ossorio, "The Human Genome as Common Heritage: Common Sense or Legal Nonsense?" The Journal of Law, Medicine ES Ethics 35 (2007), 425-439 at p. 429.
} 
against other people. But against whom do the owners of res communis have such rights? After all, they are everyone. What differentiates objects which are collectively owned in such a way from objects which nobody owns? The notion of exclusion is key here. Among objects which nobody owns, one must distinguish between objects that are in principle capable of being owned but are not (yet) owned (the res nullius of Roman Law), and objects to which the concept of ownership is utterly inapplicable. The first concept excludes no-one from freely disposing over the object, while the latter excludes everyone by declaring the object inadmissible as an object of ownership. Ossorio finds res communis to be an inadequate substitute for this notion of inadmissibility, and a look at what is and what is not excluded by res communis clearly proves her right. Ownership, even in the case of res communis, involves a right to transfer the power of disposition over a property. In the case of res communis it merely excludes such transfers by single individuals-only the community as a whole figures as the right holder with a corresponding entitlement to exercise such a right. To view the human genome as res communis is to view the patenting of genes as a transfer of the power of disposition from the community to a set of individuals who, in their patent application, have demonstrated their ability to make use of the resource. On this view, the question would no longer be whether genes are patentable in principle-that they are would follow from their being commonly owned. Rather, the question would become one of the democratic legitimacy of agreements delineating the conditions under which gene patents are to be granted.

Ownership, however, involves more than the right to transfer; it also involves the right to destroy the property. Yet surely this does not square well with the intuitions underpinning the appeal to the CHI. These seem to run in the opposite direction, aiming to protect the genome rather than to affirm humanity's right to destroy it. This suggests that the notion of res communis is ill-suited to accommodate the intuitions driving the appeal to the CHI. Designating the genome as an inherited shared property shifts the debate towards gene patents' democratic legitimacy and threatens to run counter to the purpose of protecting it.

The $\mathrm{CHI}$ as presented so far regarded the genome as a natural resource subject to common property rights. Abandoning the attempt to turn what many feel should be res nullius into res communis, I now want to explore the idea that the human genome as a repository of information can form part of our common heritage, but in the preservationist sense in which talk of such a heritage was first codified in the UNESCO's Convention for the Protection of Cultural Property in the Event of Armed Conflict of 1954, and later in The Convention Concerning the Protection of the World Cultural and Natural Heritage of 1972. This idea, 
which is more in the spirit of a res publicae than a res communis doctrine, has been advocated by Ossorio on the grounds that it "avoids the problems of creating a property right in a resource that resides within all individuals." ${ }^{26}$ Defending this idea will involve getting clear about what this other, preservationist heritage idea (PHI) is, and why the genome as a repository of information should be subsumable under it.

What makes the cultural and natural heritage interesting for this debate is that it constitutes an abstract entity composed of many concrete but discontinuous parts belonging to different people. This heritage conception gives shape to the idea that, questions of ownership aside, one could be under an obligation to preserve a resource in virtue of that resource's contribution to an abstract whole in which mankind has an interest. In the wake of World War II, the Convention for the Protection of Cultural Property contended that "damage to cultural property belonging to any people whatsoever means damage to the cultural heritage of all mankind, since each people makes its contribution to the culture of the world," 27 thus bringing into play the interests of "all mankind" in some property independently of whose property it was. In the same spirit, the 1972 Convention Concerning the Protection of the World Cultural and Natural Heritage argued that such interests could be defended while largely side-stepping issues of ownership and autonomy:

Whilst fully respecting the sovereignty of the States on whose territory the cultural and natural heritage ... is situated, and without prejudice to property rights provided by national legislation, the States Parties to this Convention recognize that such heritage constitutes a world heritage for whose protection it is the duty of the international community as a whole to co-operate. ${ }^{28}$

The notion of cultural and natural heritage at play in the PHI is tied less to people's rights to partake in the benefits of a heritage than to their duties to protect and preserve that heritage. The relationship articulated is not (primarily) one of ownership, but a fiduciary one. ${ }^{29}$ This shift of emphasis opens up the possibility of attributing heritage status to the genome without thereby generating property rights, thus circumventing the problems which a $\mathrm{CHI}$ modelled on the Convention on the Law of the Sea raised when applied to the human genome.

Ossorio notes several fruitful parallels between cultural property and the human genome. Both can be described as abstract ideas, composed of and embodied in discrete objects; both can be regarded as being simultaneously subject to both private and public

\footnotetext{
${ }^{26}$ Ossorio, p. 431.

${ }^{27}$ UNESCO, "Convention for the Protection of Cultural Property in the Event of Armed Conflict," 215-240 at p. 215.

${ }^{28}$ United Nations, "Convention Concerning the Protection of the World Cultural and Natural Heritage," U.S. Treaties and Other International Agreements (Paris, 1972), at Art. 6, $\$ 1$.

${ }^{29}$ Speaking in terms of a dichotomy between a fiduciary relationship and one of ownership is of course a simplification: preservationist duties can be part of the bundle of property rights and liabilities, as is the case with the ownership of a Picasso painting or of a house protected as historical monument.
} 
interests: they may have a value for the individual who possesses them, and whose interests can be protected (through private ownership, for example), but they also have value in virtue of being part of a larger heritage, which may entail interests in its being both preserved and publicly accessible. Ossorio also remarks that the consequences of designating the genome as part of mankind's heritage as drawn out according to the preservationist Conventions of 1954 and 1972 are well suited to promote the values underlying the move towards the CHI: the PHI calls on the owners of cultural or natural heritage property to use and preserve it "for the benefit of all humanity." ${ }^{30}$ It emphasises the "duties of possessors to preserve cultural treasures/natural wonders," to "promote scientific investigation of" and "education concerning" 31 the heritage. Besides its focus on duties, the PHI also involves rights of access in the form of assumptions that the "benefits of exposure to cultural and natural heritage" will be "available to people without regard to nationality or generation." 32 In sum, this version of the heritage doctrine promises to capture many of the concerns regarding the human genome.

While Ossorio recognises that the PHI is fitting as far as its logical structure and consequences are concerned, she has strong reservations about declaring the human genome to be part of mankind's heritage in the first place:

Does this urge to preserve reflect a certain inappropriate hubris regarding the centrality of human beings in the grand scheme of things?... Does a desire to protect the human genome indicate an over-inflated belief in the power of DNA to determine personal identity? Before national governing bodies enact policies that venerate the human genome, reasons for placing more significance on human genomes than on other biological or physiological substances ought to be carefully delineated. ${ }^{33}$

It may be true that there is a danger of unjustified "veneration" of the human genome, driven perhaps by anthropocentric ideas. But it does not follow that the sole alternative we have in making sense of preservationist aspirations is to take them in the minimal, constitutive sense that Ossorio suggests when she writes that " $[t]$ o the extent that 'the human genome' is concretized in each human being as a particular genome, the human genome will exist so long as human beings exist." ${ }^{34}$ There are reasons to think that the human genome ought to be preserved not just in this minimal sense, but in the rich, qualitative sense in which it should be preserved in its diversity. These reasons revolve around the idea that the genome forms a repository of information, both as a record of our biological bistory, and as a collection of instructions for the development of phenotypic traits which may prove useful in the future.

\footnotetext{
${ }^{30}$ Ossorio, p. 431.

31 Ibid.

${ }^{32}$ Ibid.

${ }^{33}$ Ibid., p. 432.

${ }^{34}$ Ibid.
} 
This line of thought is only as clear as the notion of information it appeals to, so this notion must be clarified in two respects: first, what do we mean by information? And second, what is it information about? In answering the first question, biologists since J. B. S. Haldane have found it useful to turn to the technical definition of "information" advanced by Claude Shannon: information is what enables the narrowing down of prior uncertainty. ${ }^{35}$ It is the quantity we obtain if we measure the difference between the ignorance or uncertainty of a receiver before receiving a message and the receiver's uncertainty after receiving the message. This notion of information can be used to measure the genome's information capacity: genetic information is held in a sequence of nucleotides in much the same way that computer information is held in a sequence of noughts and ones, only that instead of using a binary code as computers do, DNA uses a quaternary code. ${ }^{36}$ However, while it is one thing to calculate the information capacity of the human genome, it is quite another to estimate its actual information content. In the course of evolution, gene duplications and deletions have spawned a great diversity of genetic material. Much of human DNA is currently thought to consist of "pseudogenes" ${ }^{7}$ that are recognisably related to proteincoding genes, but are faulty in a way that results in their information not getting translated into proteins. Moreover, since molecular evolution goes on even after the loss of function, the degeneration and duplication of nonfunctional copies is likely to have littered the genome with repetitive nonsense (though future research might well find functionality even here). Consequently, the portion of the human genome that codes for proteins is thought to amount to around 2 per cent.

With this understanding of genetic information, we can turn to our second question: What is that information about? There are at least two senses in which DNA molecules carry information about something. The first is the sense in which all molecules necessarily carry information, namely information about themselves: every molecule embodies information about its own molecular structure, and DNA embodies information about nucleic acids strung together in pairs on double-stranded sugar-phosphate backbones. This is the information that DNA carries independently of what we have called its "double nature," and solely in virtue of being one phenotypic building block among others. But there is a further sense in which DNA conveys information, and that is the sense in which it carries instructions for bow to build bodies. It is in this sense that genes are "Life's instructions."

\footnotetext{
${ }^{35}$ Claude Shannon, “A Mathematical Theory of Communication,” Bell System Technical Journal 27.3 (July 1948), 379-423.

${ }^{36}$ The information content of each "letter" in a genetic sequence is two bits: before learning the letter's identity, there are four possibilities: A, C, T, and G; afterwards, there remains only one. In going from four possibilities to one, we halve our uncertainty twice. If we apply this measure to the human genome, its total information capacity will range in the gigabits $\left(10^{9} \mathrm{bits}\right)$.

${ }^{37}$ Greg Elgar and Tanya Vavouri, "Tuning in to the Signals: Noncoding Sequence Conservation in Vertebrate Genomes,” Trends in genetics: TIG 24.7 (July 2008), 344-352 at p. 345.
} 
Talk of "instructions" highlights that genetic information is not information in the sense of a "blue-print," i.e. of a scaled-down version of something translated into a lower set of dimensions, where there is a one-to-one correspondence between features of the blue-print and features of what it is a blue-print of. Rather, it is information in the sense of a "recipe," where differences in the instructions correspond to differences in the product. ${ }^{38}$ This is important because building from blue-prints is reversible, while building from recipes is not (hence the practice of industrial espionage). By directing the synthesis of the structural and catalysing materials of the body, genes act as recipes in just this sense. It is what sets them apart from other molecules, and grounds talk of their double nature as both chemical compounds and information carriers. Genes, we might say, are nature's know-how.

This understanding of information sharply brings out what the information value of DNA consists in: there are innumerable ways in which nucleic acids can be strung together without fulfilling any function, let alone serving as templates for the synthesis of complex and stable molecules. If the gene pool exhibits such a high concentration of functional sequences, it is as a result of a process which, over the eons, has partitioned the immense field of possible combinations into those that work, and those that do not. DNA possesses not just information capacity, but actual information content as a result of having been subjected to strong selective pressures paring away the non-functional. It is to isolate this content that cDNA is synthesised: cDNA encapsulates the 2 per cent of signal in isolation from the 98 per cent of noise while being both shorter than DNA and stabler than mRNA.

This information constitutes a type of know-how, instructions for how to build phenotypes that successfully navigate specific environments, produce nutrients, resist diseases and adapt to changing circumstances. This is the sense in which the genome is, in Richard Dawkins's words, a "genetic book of the dead": 39

As the generations go by, the whole set of genes of a species—the gene pool-is carved and whittled, kneaded and shaped, so that it becomes good at making successful individuals.... [I] $\mathrm{n}$ this sense ... the species is learning from its experience in the art of building good individual bodies, and it stores its experiences in coded form in the set of genes in the gene pool.... The information that the experience packs away is information about ancestral environments and how to survive them. ${ }^{40}$

This passage brings out one reason why the human genome should possess heritage value: it can lay at least as much claim to being worthy of preservation as any other vestiges and records of humanity's past, such as ruins, artefacts and palimpsests. The genome forms an immense repository of information, a record of our biological bistory which we are only beginning to be able to read. Preserving the human genome in the rich sense which includes

\footnotetext{
38 The analogy with recipes or instructions is defended for instance in Marian Stamp Dawkins, "Let Them Think Cake,” Nature 402 (1999), 234-235.

${ }^{39}$ Richard Dawkins, Unweaving the Rainbow (Boston and New York: Mariner Books, 1998), p. 234.

${ }^{40}$ Ibid., p. 239.
} 
the preservation of its diversity is key to preserving this informational heritage, much as preserving a variety of documents in a library is key to preserving its value as a repository of information. This does not give us license to say that the human genome is more valuable than other genomes, period. But the focus on the human genome need express no more than the fact that the human genome as a record of our history is more important to us, a fact which is hardly surprising. ${ }^{41}$

A second reason for valuing the genome is that it is not just a record of our evolutionary history and the challenges faced therein, but also an asset for future developments: it is a collection of instructions for the development of many traits and talents, some of which may not now be expressed, but many of which might provide valuable know-how for protein synthesis, resistance to disease, and other forms of survival and flourishing (compare the "antifreeze" gene found in Arctic fish which was spliced into tomatoes to save them from frost damage). Viewing the genome as a repository of potentially useful information in this sense gives us reasons to value genomes as resources for future scientific, medical, and biotechnological development. Here, the privileging of human genetic material is a matter of degree, and is analogous to the favouring of model organisms that are genetically similar to us in biomedical research: the closer a genetic sequence housing some expressed or latent talent matches our own, the more likely it is to be exploitable for us.

This view of the genome as a repository of talents also gives us reasons to value genetic diversity. Writing about Sub-Saharan Africa, where this diversity seems highest, E. O. Wilson emphasises the potential inherent in diversity: ${ }^{42}$

It has not escaped the attention of human biologists and medical researchers that the genes of modern-day Africans are a treasure house for all humanity. They possess our species' greatest reservoir of genetic diversity ... an asset, prized for the adaptability it provides all of us during an increasingly uncertain future. Humanity is strengthened by a broad portfolio of genes that can generate new talents, additional resistance to diseases, and perhaps even new ways of seeing reality. ${ }^{43}$

Wilson then goes on to call for "a new ethic of . . . hereditary variation," one that "places value on the whole of diversity." ${ }^{44}$ Whether diversity is non-instrumentally valuable to us, and whether such a value would apply to the human genome, are questions I want to leave open here. Instrumentally, however, genetic diversity is straightforwardly valuable in that

\footnotetext{
${ }^{41}$ This point is spelled out in Bernard Williams, “The Human Prejudice," Pbilosophy as a Humanistic Discipline, ed. Adrian W. Moore (Princeton and Oxford: Princeton University Press, 2006), 135-154 at p. 139.

${ }^{42}$ That genetic diversity among humans is highest south of the Sahara became clear in 2010, when all of the protein-coding sequences of the genome were published for four Khoisan hunter-gatherers and for a Bantu from a neighbouring tribe. Outward similarity notwithstanding, the four Khoisan differed more from one another than the average European differs from the average Asian. See Stephan C. Schuster et al, "Complete Khoisan and Bantu Genomes from Southern Africa," Nature 463.7283 (2010), 943-947.

${ }^{43}$ Edward Owen Wilson, The Social Conquest of Earth (London and New York: Liveright, 2012), pp. 80-81.

${ }^{44}$ Ibid.
} 
it increases resilience towards epidemics: the more genetic types exist in a population, the less likely it is that an epidemic will drive it to extinction. Moreover, high genetic diversity makes it not only more likely that traits of interest and the genetic sequences associated therewith will be found, but also that they will be generated: a diverse gene pool stands a better chance of hitting upon a mutation of interest. But Wilson also points to ways in which diversity might prove instrumentally valuable in less immediate ways: the gene pool is a "treasure house," a "portfolio" of the talents evolution as given rise to. In this sense, it is nature's oewure, comparable to the cultural heritage as the cumulative record of the achievements of humanity. From this perspective, the thought that "the human genome will exist so long as human beings exist" provides little solace to preservationists.

It might be objected that the genome's protean nature renders the project of preserving it absurd. What would it even mean to preserve something that undergoes continuous alteration? The distinction between compounds and the information they carry can once more help us focus the discussion: while there is no question that the set of all genetic molecules in a species is subject to continuous modifications through replication, disassembly and reassembly, there is considerable inertia at the informational level. 6.3 million years after the speciation event that separated us from chimpanzees, we still share around 98.5 per cent of our genetic information with them; as for mice, the figure is 85 per cent after 80 million years. ${ }^{45}$ These figures illustrate the general point that evolutionary success depends as much on the ability to be conservative and preserve successful configurations once they are discovered as on the ability to generate innovation through random variation. What works endures and is, on human time-scales, quite stable. To the extent that there is continual alteration at the informational level, one can retort that it is a feature of our cultural or natural heritage as much as of the genome: all three, in their own way, undergo continuous change.

But is every novelty equally worthy of inclusion in the heritage? In the case of the cultural and natural heritage, only a small fraction is found to be of interest at any particular time, even though (and perhaps also because) new works of nature and culture are continuously being generated. Uniqueness is not a sufficient condition for inclusion in the heritage. Further conditions have to be met, such as the possession of historical value, aesthetic merit or scientific interest. This leads us to the question of what these further conditions might be in the case of the genome.

On the assumption that we have to selective, deciding by which criteria we should be so raises thorny issues. Some, like Ossorio, take this path to be objectionable in principle. She suggests that problems would arise

${ }^{45}$ Nick Patterson et al, "Genetic evidence for complex speciation of humans and chimpanzees," Nature 441 (June 2006), 1103-1108 at p. 1103. 
... with attempts to preserve only a portion of people's genomes, either in vitro or in vivo. This approach might result in attempts to assign the essence of humanity, or the unifying properties of the human species, to a particular set of DNA sequences. Such a policy likely would place too much importance and value on DNA. Furthermore, finding the genetic essence of humanity is probably an impossible task, even if some group of people could agree on what constitutes the essence of humanity. ${ }^{46}$

Leaving to one side the questionable assumption that, for reasons Ossorio does not divulge, we should expect selective preservation to focus on a putative "essence of humanity," this passage is revealing in its assumption that it is preservation in vitro or in vivo that is at stake. ${ }^{47}$ If we distinguish between the chemical compound and the information it carries, we can see that it is by no means necessary that genetic information should be preserved in either of those ways. As Watson pointed out, DNA is useful in virtue of the information it carries, while the information carrier is itself of little interest to us. We have already entered the age in which we can go from digitised genome sequence information to a fully functional genetic molecule, which means that there is a third option: preservation in silico. ${ }^{48}$ Not only is this the more practical option, but it is also the least problematical from an ethical point of view. It avoids the problem of having to decide whose genotype to preserve by abstracting away from the concrete analog molecule towards a digitally encoded representation of a pool of information, and in view of the data-storage solutions available today, the pressure to be selective in preservation in silico is very low. This is fortunate, because the PHI as applied to the genome raises a problem of its own: while we can evaluate the historical value, aesthetic merit or scientific interest of what is traditionally included in our cultural and natural heritage, the genome presents us with the peculiar epistemic difficulty that the significance of a particular sequence is probably not yet fully transparent to us. The default attitude encouraged thereby is that as much genetic information as possible should be preserved until we can adequately assess its value.

Any piece of genetic information derives its value primarily from being associated with some phenotypic trait of interest to us. Traits of interest include immediately beneficial traits, such as resistance to particular diseases, or the synthesis of therapeutic proteins, but they might also be of interest by being potentially harmful, as the case of the increased risk of cancer associated with $B R C A 1$ and $B R C A 2$ illustrates. What gives us reason to value a

\footnotetext{
${ }^{46}$ Ossorio, p. 433.

${ }^{47}$ If the notion of a genetic "essence of humanity" makes sense at all on this reading, it must be taken to refer to the reference genome constructed through statistical means by the GRC. But even projects such as the GRC's measure their success by their ability to capture the breadth of genetic diversity within a species.

${ }^{48}$ In 2009, the J. Craig Venter Institute developed a molecular engineering method to construct synthetic and natural genes, genetic pathways and entire genomes. In 2010, they created a bacterial cell controlled by an entirely chemically synthesized genome. See Daniel G. Gibson et al., "Enzymatic Assembly of DNA Molecules up to Several Hundred Kilobases," Nature Methods 6 (2009), 343-345; Daniel G. Gibson et al., "Creation of a Bacterial Cell Controlled by a Chemically Synthesized Genome," Science 329.5987 (2010), 52-56.
} 
particular sequence of DNA is ultimately the role that this sequence does or could play in our lives, where this role is to be understood in the widest sense as involving not only the ways it is used as information within the practices of biomedical research and treatment, but also the ways in which its phenotypic effects come to play a role in the lives of the agents whose environment they shape. Thus, in pursuing the question of the value of genetic information all the way to the value of individual traits, we transform it into the more familiar, though no less difficult question of what traits we value in individuals, which leads to the welcome conclusion that questions of "genethics" must ultimately be grounded in the wider concerns of ethics and politics.

\section{IV}

Sixty years after its discovery, the human genome has become a focus of attention in disciplines as various as forensics, jurisprudence, medicine, and political philosophy. Among the leading ideas that have emerged in the course of these developments is the idea that the human genome forms part of the common heritage of mankind. I have attempted to give shape to and justify this idea by examining what sets DNA apart from other molecules. The guiding insight thereby was that genetic molecules possess a peculiar double nature: they are both relatively inert analog chemical compounds and carriers of digitally encoded information of a particular kind. Corresponding to these two aspects of DNA, we distinguished two ways in which concerns about the future of the human genome can be made explicit under the title of the common heritage idea. On one view, the SPHI, the human genome is a natural resource belonging to everybody, and we should vest in mankind as a whole a property right to a discontinuous natural resource distributed over all human cells. If modelled on the United Nations Convention on the Law of the Sea, this view lays emphasis on the equitable sharing of all benefits derived from the human genome. Because it would create property rights to something that is partly in our own and partly in other people's bodies, however, the SPHI conflicts with prevalent ideas about autonomy and self-ownership. Moreover, it fails to capture the preservationist underpinnings of the appeal to the common heritage idea.

The alternative view explored here, the PHI, articulates a fiduciary relationship between mankind and a collection of information. This notion is modelled on preservationist concerns about the future of the cultural and natural heritage. It conceives of the genome not as res communis, but as res publicae; it substitutes rights of access for rights of ownership, and lays emphasis on duties of preservation, promotion of scientific investigation, and education concerning the heritage. What animates this view is the realisation that the genome forms a valuable repository of information, both as a record of our biological history and as 
a collection of instructions for potentially useful phenotypic traits. Consequently, this repository of information should be preserved in as much of its diversity as possible until we are in a position to fully assess its value. But since it is to the information and not to its physical substrate that the value attaches, this preservation may take place in silico, avoiding many of the problems afflicting preservation in vivo or in vitro.

Having sketched how a conception of the CHI which seems to coherently capture at least some of the concerns voiced in the gene patent debate could be spelled out and justified, we can return to the question of its relation to the patent system. Following Ossorio, I have argued that the implications of applying the PHI to human genome as modelled on the UNESCO's attitude towards the cultural and natural heritage would, in the first instance, be limited to duties of preservation and, possibly, rights of access. This has the advantage of allowing us to avoid the creation of property rights in the human genome (either in the abstract or in its individual realisations), and, as Ossorio notes, "may be the least difficult to implement and the most amenable to fulfilling the goals of common heritage proponents." ${ }^{9} 9$

The principle implication of an articulation of people's intuitions about the genome in terms of the PHI view is the dissolution of the perceived conflict with the patent system, because these intuitions are directed away from issues of ownership and ownership-related concepts and towards issues of preservation and access. Moreover, the patent system could be seen as being supportive of the various preservationist concerns discussed above. On the one hand, it provides strong incentives for research and the building of research databases in this area. On the other hand, the patent databases themselves form an in silico record of information, and one which is geared towards the dissemination of that information. By encouraging both the protection and the disclosure of information, the patent system is doubly subservient to preservationist ends.

Yet the disambiguation of DNA's double nature brings out an element that is slightly askew in reports of the Supreme Court's decision. The message had widely been that the building blocks of life had been released from the grip of economic interests. But a closer look at the decision reveals a different story. While the Court argued that DNA that has merely been isolated (gDNA) is a product of nature and not patent-eligible, cDNA, which is created from the DNA-derived template for protein synthesis, continues to be patent-eligible. In view of DNA's double nature, however, this seems to fail to resolve many of the issues at the heart of the debate: while physically cDNA is clearly distinct from naturally occurring DNA in missing all non-coding segments, it is functionally identical with naturally occurring DNA where protein synthesis is concerned. gDNA may have far greater information capacity than cDNA, but its information content is, for current purposes, equivalent to that of gDNA.

\footnotetext{
${ }^{49}$ Ossorio, p. 437.
} 
The judgement can thus be seen to hinge on the distinction between physical identity and informational identity to prevent the patenting of entire gene sequences while continuing to allow the patenting of the bits that are actually useful. The decision does not make it sufficiently clear why claims to information encoded in the form of cDNA should be less problematic than claims to information enshrined in gDNA.

By preserving the patentability of cDNA, the Supreme Court could be said to have paid but lip service to Watson, since there is still an important sense in which "Life's instructions" are patentable. cDNA is even both medically and commercially the more important type of molecule, as geneticist Eric Lander pointed out to the Court:

The vast majority of the medically and commercially important biotechnology products developed over the past quarter century are protected by patents on isolated DNA molecules that are non-natural compositions of matter, such as cDNA and recombinant DNA molecules-for such uses as artificially producing therapeutic proteins. ${ }^{50}$

As far as innovation is concerned, then, the Court's decision leaves the chief incentives untouched, and serves some of the patent system's core objectives.

However, the Supreme Court's decision does have consequences for what might we might consider as falling under the rights of access to genetic information. Patents on cDNA are easier to work around than patents on gDNA, which means that tests involving the gDNA but not the cDNA version of a gene can now be offered without fear of patent infringement. ${ }^{51}$ For this reason, the Supreme Court's decision is likely to increase patient access to diagnostic genetic testing and to reduce the tests' prices as more firms start offering them. Also, the Court's decision does away with concerns about whole-genome sequencing being impeded by gDNA patents, which will encourage firms to offer tests which rely on such whole-sequencing methods. ${ }^{52}$ Other than that, the effect of the Court's decision will be limited by the fact that the race for whole-gene patenting is largely over, and many gDNA patents either have already expired or will expire soon. ${ }^{53}$ The DNA patents that will be of practical concern in the future are likely to be patents on cDNA and synthetic DNA.

At the dawn of the age of genomics, gaining a nuanced understanding both of genetics and of the ethical and political issues it raises is key to an early adoption of the right policies in our dealings with the human genome. The pace of developments requires a constant reevaluation of the dynamic relation between public opinion and the legal framework these developments take place in. On the side of the legal framework, this means that while most

\footnotetext{
${ }^{50}$ Eric S. Lander, "Brief amicus curiae of United States in support of neither party," Association for Molecular Pathology v. Myriad Genetics 569 U.S. 12-398 (2013).

${ }^{51}$ Arti K. Rai and Robert Cook-Deegan, "Moving Beyond 'Isolated' Gene Patents," Science 341.6142 (2013), 137-138 at p. 137.

${ }^{52}$ Ibid., p. 138.

${ }^{53}$ Ibid.
} 
of the patents on whole human genes granted in the genomics gold rush of the nineties are set to expire, new questions concerning bacterial DNA and synthetic DNA are moving into view. On the side of public opinion, it means that the normative considerations in the light of which legal practices are assessed cannot be presumed to be just a matter of people's established attitudes towards these questions. The complex, groundbreaking nature of these issues implies that our uninformed opinion may well fail to coincide with the opinion we would hold if we were better informed. Moreover, what opinion one holds or could hold is itself a function of numerous factors, and importantly rests on a sense of what is possible. In the public debate over these issues, it is therefore of paramount importance to secure transparency and education concerning genomics, since it is precisely the boundaries of the possible that are being pushed. 